\title{
BUT I'M AN AMERICAN! A TeXT-BASEd RATIONALE FOR DISMISSING F-SQUARED SECURITIES FRAUd ClAIMS AFTER MORRISON V. NATIONAL AUSTRALIA BANK
}

\begin{abstract}
Alex Reed*
\section{INTRODUCTION}

On June 24, 2010, the United States Supreme Court issued its muchanticipated decision in Morrison v. National Australia Bank Ltd. ${ }^{1}$ After concluding that Section 10(b) of the Securities Exchange Act of 1934 does not apply extraterritorially, the Court announced a new standard for determining whether a particular securities transaction is subject to the antifraud provisions of the federal securities laws. ${ }^{2}$ Under this new transactional test, Section 10(b) applies only to purchases and sales of securities listed on U.S. stock exchanges and domestic transactions in other securities. $^{3}$

Although meant to be a bright-line rule, the transactional test has generated considerable controversy on account of its ambiguity. Plaintiffs have seized on this uncertainty to argue that securities fraud claims brought by U.S. investors against foreign issuers remained viable post-Morrison even when the relevant securities were purchased on foreign exchanges (" $f$ squared claims"). ${ }^{4}$ To date, courts confronted with this argument have engaged in unnecessarily protracted analyses of the Supreme Court's rationale and policy objectives in announcing the test rather than focusing on the text of the transactional test itself.

This Article concludes that the transactional test's basis in the text of the Exchange Act provides the simplest, most direct means for disposing of f-squared claims. Part I provides a brief overview of the state of the law
\end{abstract}

* Assistant Professor of Legal Studies, Terry College of Business, University of Georgia.

1. Morrison v. Nat'l Austl. Bank Ltd. (Morrison III), 130 S. Ct. 2869 (2010).

2. Id. at $2883-84$.

3. $I d$. at 2884 .

4. See infra text accompanying note 122 . 
prior to Morrison. Part II traces Morrison's rise through the district and circuit courts up to the United States Supreme Court. Part III documents fsquared plaintiffs' attempts to circumvent Morrison and analyzes lower courts' applications of the transactional test. Part IV proposes a text-based rationale for dismissing f-squared claims that avoids the attenuated, policybased analyses employed by lower courts to date. Finally, Part V examines the proposed standard's applicability beyond the f-squared context.

\section{The CONDUCT AND EFFECTS TESTS}

Prior to the Supreme Court's ruling in Morrison, the Second Circuit employed two distinct tests to determine the extraterritorial reach of Section 10(b). Satisfaction of either test was sufficient to confer subject matter jurisdiction, and courts sometimes merged the tests to obtain jurisdiction over cases that could not satisfy either test independently. ${ }^{5}$

The first analysis was known as the "effects test" and was announced in Schoenbaum v. Firstbrook. ${ }^{6}$ Under the effects test, subject matter jurisdiction was deemed to exist if "the wrongful conduct [abroad] had a substantial effect in the United States or upon United States citizens.",

The second inquiry was known as the "conduct test" and was announced in Leasco Data Processing Equipment Corp. v. Maxwell. ${ }^{8}$ Under the conduct test, subject matter jurisdiction was deemed to exist if investors located abroad were harmed by conduct emanating from the United States. ${ }^{9}$ Significantly, the quantity and quality of wrongful conduct necessary to confer jurisdiction varied depending on whether the injured investors were Americans: "When the alleged damages consisted of losses to American investors abroad, it was enough that acts 'of material importance' performed in the United States 'significantly contributed' to that result; whereas those acts must have 'directly caused' the result when losses to foreigners abroad were at issue." 10

In recognition of the Second Circuit's preeminence vis-à-vis application of the federal securities laws, variations of the conduct and effects tests were adopted by the Third, Fifth, Seventh, Eighth, Ninth, and D.C. Circuits. ${ }^{11}$ Although application of the effects test was relatively

5. Dennis R. Dumas, United States Antifraud Jurisdiction over Transnational Securities Transactions: Merger of the Conduct and Effects Tests, 16 U. PA. J. INT'L Bus. L. 721, 730-32 (1995).

6. 405 F.2d 200, 206-09 (2d Cir. 1968).

7. S.E.C. v. Berger, 322 F.3d 187, 192 (2d Cir. 2003).

8. 468 F.2d 1326, 1336-37 (2d Cir. 1972).

9. Berger, 322 F.3d at 192-93.

10. Morrison III, 130 S. Ct. at 2879 (quoting Bersch v. Drexel Firestone Inc., 519 F.2d 974, 993 (2d Cir. 1975)).

11. Danielle Kantor, Note, The Limits of Federal Jurisdiction and the F-Cubed Case: 
uniform across circuits, the degree of activity required to satisfy the conduct test varied widely. ${ }^{12}$ For example, the D.C. Circuit required that the conduct at issue constitute a prima facie violation of Section $10(\mathrm{~b}) \cdot{ }^{13} \mathrm{In}$ contrast, the Third Circuit required only that there be some domestic conduct in furtherance of the fraud. ${ }^{14}$ The Fifth, Seventh, Eighth, and Ninth Circuits have taken approaches that fall somewhere between these two extremes. ${ }^{15}$

Over the course of their forty-year reign, the conduct and effects tests were subjected to extensive criticism. The chief complaint was that the tests were unpredictable and inconsistently applied at both the intra-circuit and inter-circuit levels. ${ }^{16}$ One commentator went so far as to suggest that courts applying the tests "often seem[ed] to work backwards, first assuming jurisdiction over a particular case and then shaping an analysis to support the assertion of jurisdiction." 17 Consequently, a number of scholars proposed that the conduct and effects tests be revised or eliminated altogether in favor of a bright-line rule specifying the extraterritorial reach of U.S. securities laws. ${ }^{18}$ After decades of inaction by Congress and the United States Supreme Court, the fate of the conduct and effects tests was

Adjudicating Transnational Securities Disputes in Federal Courts, 65 N.Y.U. ANN. SuRV. AM. L. 839, 866-68 (2010).

12. Gregory K. Matson, Note, Restricting the Jurisdiction of American Courts over Transnational Securities Fraud, 79 GEO. L.J. 141, 152-53, 158-61 (1990) (discussing circuit courts' differing applications of the conduct test); David Michaels, Note, Subject Matter Jurisdiction over Transnational Securities Fraud: A Suggested Roadmap to the New Standard of Reasonableness, 71 CoRNELL L. REV. 919, 926 (1986) (noting that the Second Circuit, in applying the conduct test, sought to balance the quantity and quality of domestic and foreign conduct, whereas other circuits "rel[ied] instead on the distinction between significant and preparatory acts").

13. James J. Finnerty, III, Note, The "Mother Court" and the Foreign Plaintiff: Does Rule 10b-5 Reach Far Enough?, 61 FordHAM L. REV. S287, S305 (1993).

14. Michael Wallace Gordon, United States Extraterritorial Subject Matter Jurisdiction in Securities Fraud Litigation, 10 FLA. J. INT'L L. 487, 521 (1996).

15. Kantor, supra note 11, at 867-68.

16. E.g., Hannah L. Buxbaum, Multinational Class Actions Under Federal Securities Law: Managing Jurisdictional Conflict, 46 Colum. J. TransnaT'L L. 14, 17 (2007); Stephen J. Choi \& Linda J. Silberman, Transnational Litigation and Global Securities Class-Action Lawsuits, 2009 WIS. L. REV. 465, 467-68 (2009); Paige Keenan Willison, Note, Europe and Overseas Commodity Traders v. Banque Paribas London: Zero Steps Forward and Two Steps Back, 33 VAND. J. TRANSNAT'L L. 469, 472 (2000).

17. Matson, supra note 12, at 149.

18. E.g., Stephen J. Choi \& Andrew T. Guzman, The Dangerous Extraterritoriality of American Securities Law, 17 Nw. J. INT'L L. \& Bus. 207, 228-29 (1996); Erez Reuveni, Extraterritoriality as Standing: A Standing Theory of the Extraterritorial Application of the Securities Laws, 43 U.C. DAVIS L. REV. 1071, 1071-72 (2010); Margaret V. Sachs, The International Reach of Rule 10b-5: The Myth of Congressional Silence, 28 ColuM. J. TRANSNAT'L L. 677, 682 (1990). 
finally decided on June 24, 2010 when the Supreme Court handed down its opinion in Morrison.

II. MORRISON V. NATIONAL AUSTRALIA BANK LTD.

\section{A. The Facts}

National Australia Bank Ltd. ("National" or the "Bank"), a corporate entity organized under the laws of Australia and headquartered in Melbourne, ${ }^{19}$ was Australia's largest bank. ${ }^{20}$ Its ordinary shares-the equivalent of common stock in the United States - traded on the Australian Securities Exchange and other foreign securities exchanges but not on any U.S. exchange. ${ }^{21}$ National's American Depositary Receipts, ${ }^{22}$ however, were listed on the New York Stock Exchange. ${ }^{23}$

In 1998, National acquired HomeSide Lending Incorporated ("HomeSide"), ${ }^{24}$ a Florida-based mortgage servicing company. ${ }^{25}$ Financial institutions paid HomeSide a fee to collect and process their customers' mortgage payments. ${ }^{26}$ The servicing rights associated with these mortgages represented a future income stream to HomeSide, the present value of which depended, in part, on the likelihood that the underlying loans would be prepaid. ${ }^{27}$ Consequently, to calculate the present value of HomeSide's mortgage-servicing rights, company executives had to make certain assumptions regarding the likelihood of prepayment. ${ }^{28}$ This value was

19. In re Nat'l Austl. Bank Sec. Litig. (Morrison I), No. 03 Civ. 6537 (BSJ), 2006 WL 3844465 , at $* 1$ (S.D.N.Y. Oct. 25, 2006).

20. $I d$.

21. Id.

22. An American Depositary Receipt (“ADR") is a:

... receipt that is issued by a depositary bank that represents a specified amount of a foreign security that has been deposited with a foreign branch or agent of the depositary, known as the custodian. The holder of an ADR is not the title owner of the underlying shares; the title owner of those shares is either the depositary, the custodian, or their agent. ADRs are tradable in the same manner as any other registered American security, may be listed on any of the major exchanges in the United States or traded over the counter, and are subject to the [federal securities laws]. This makes trading an ADR simpler and more secure for American investors than trading in the underlying security in the foreign market.

Id. at *1 n.3 (quoting Pinker v. Roche Holdings Ltd., 292 F.3d 361, 367 (3d Cir. 2002)).

23. $I d$. at $* 1$.

24. Id.

25. Morrison I, 2006 WL 3844465 , at *1.

26. Morrison III, 130 S. Ct. at 2875.

27. $I d$.

28. Id. at $2875-76$. 
ultimately incorporated into National's public financial statements. ${ }^{29}$

Initially, the acquisition appeared to be a boon for National. Between 1998 and 2001, the Bank consistently reported record profits. ${ }^{30}$ National and three of the four individual defendants publicly attributed this success to strong performance by HomeSide. ${ }^{31}$

On July 5, 2001, however, National announced that it would record a $\$ 450$ million write-down to reflect the decreased value of HomeSide's mortgage-servicing rights. ${ }^{32}$ In response, the price of National's ordinary shares and ADRs fell by more than 5\%. ${ }^{33}$ Then, on September 3, 2001, National announced a second write-down of $\$ 1.75$ billion. $^{34}$ Of that amount, \$400 million represented the devaluation of HomeSide's mortgage-servicing rights. ${ }^{35}$ Another $\$ 760$ million was attributed to mistaken assumptions in HomeSide's valuation model. The remaining $\$ 590$ million represented loss of goodwill. ${ }^{36}$ As a result of the September write-down, the price of National's ordinary shares fell by almost $13 \%$ while the price of its ADRs fell by more than $11 \%{ }^{37}$

On January 30, 2004, four individuals filed a consolidated class action complaint against National, HomeSide, and certain individual defendants ${ }^{38}$ in the United States District Court for the Southern District of New York. ${ }^{39}$ The complaint alleged violations of Sections 10(b) and 20(a) of the Exchange Act and SEC Rule 10b-5. ${ }^{40}$ Plaintiffs claimed that HomeSide "knowingly used unreasonably optimistic . . . assumptions or methodologies" in valuing its mortgage-servicing rights and that the defendants made materially false and misleading statements regarding HomeSide's "profitability, economic health, and its contribution to [National].",41

Three of the four plaintiffs - Russell Owen and Brian and Geraldine

29. Id. at 2875 .

30. Id.

31. Id.

32. Id. at $2875-76$.

33. Morrison I, 2006 WL 3844465 , at $* 2$.

34. Morrison III, 130 S. Ct. at 2876.

35. Id.

36. $I d$.

37. Morrison I, 2006 WL 3844465 , at $* 2$.

38. The individual defendants included: (1) Frank Cicutto, National's managing director and chief executive officer; (2) Hugh Harris, HomeSide's chief executive officer; (3) Kevin Race, HomeSide's chief operating officer; and (4) W. Blake Wilson, HomeSide's chief financial officer. Id. at*1.

39. Consolidated Class Action Complaint, Morrison I, 2006 WL 3844465 (S.D.N.Y. Oct. 25, 2006) (No. 03-06537).

40. Morrison I, 2006 WL 3844465, at *1.

41. Morrison v. Nat'l Austl. Bank Ltd. (Morrison II), 547 F.3d 167, 169 (2d Cir. 2008). 
Silverlock (the "Australian Plaintiffs") ${ }^{42}$ — were Australian residents who purchased National's ordinary shares on the Australian Securities Exchange. ${ }^{43}$ The Australian Plaintiffs sought to represent a class of foreign purchasers of National's ordinary shares. ${ }^{44}$ The fourth plaintiff, Robert Morrison (the "Domestic Plaintiff"), ${ }^{45}$ was a United States resident who purchased National's ADRs on the New York Stock Exchange. ${ }^{46}$ Morrison sought to represent a class of American purchasers of National's ADRs. ${ }^{47}$

\section{B. The District Court Opinion}

On March 11, 2004, the defendants moved to dismiss the consolidated complaint for lack of subject matter jurisdiction with respect to the Australian Plaintiffs and for failure to state a claim with respect to the Domestic Plaintiff. ${ }^{48}$ On October 25, 2006, Judge Barbara Jones granted both motions. $^{49}$

In ruling on the defendants' motion to dismiss for lack of subject matter jurisdiction, Judge Jones' analysis focused on whether HomeSide's Florida-based activities were sufficient to satisfy the conduct test. The Australian Plaintiffs argued that but-for HomeSide's accounting manipulation in Florida, National's public statements would not have been fraudulent, whereas the defendants asserted that "the alleged securities fraud was committed - if at all—only when [National] distributed the allegedly false information ... abroad."

Although a "close call," the court found that it lacked subject matter jurisdiction over the Australian Plaintiffs' claims. ${ }^{51}$ Specifically, Judge Jones held that the conduct test was not satisfied because HomeSide's activities in the United States were "at most, a link in the chain of an alleged overall securities fraud scheme that culminated abroad."

Before concluding, the court addressed the defendants' motion to dismiss for failure to state a claim vis-à-vis the Domestic Plaintiff. After noting that economic loss is an essential element of a cognizable securities

42. Morrison III, $130 \mathrm{~S}$. Ct. at 2876.

43. Morrison I, 2006 WL 3844465, at *2.

44. Morrison II, 547 F.3d at 169.

45. Morrison I, 2006 WL 3844465, at *2.

46. Id.

47. Morrison II, 547 F.3d at 169.

48. Morrison I, 2006 WL 3844465, at *2, *8.

49. Judge Jones noted that the defendants did not include the Domestic Plaintiff's claims in their motion to dismiss for lack of subject matter jurisdiction, since " $[t]$ here is no dispute that the securities law extends to protect domestic investors who purchase securities in domestic markets." Id. at *2 n.6.

50. Id. at $* 5$.

51. Id. at $* 8$.

52. Id. 
fraud claim, Judge Jones held that dismissal was warranted because the Domestic Plaintiff had failed to allege any damages. ${ }^{53}$

\section{The Circuit Court Opinion}

On February 13, 2007, the plaintiffs filed a notice of appeal challenging the district court's dismissal of the Australian Plaintiffs' claims for lack of subject matter jurisdiction. ${ }^{54}$ Significantly, the Domestic Plaintiff's claims were not appealed. ${ }^{55}$ On October 23, 2008, the Second Circuit affirmed the district court's ruling. ${ }^{56}$

At the outset of its opinion, the Second Circuit acknowledged that it was being called upon "to revisit the vexing question of the extraterritorial application of the securities laws." ${ }^{, 57}$ After summarizing the relevant tests, the court noted that the appellants were not relying on the effects test to establish subject matter jurisdiction. ${ }^{58}$ Consequently, the court limited its analysis to the conduct test, which required that the Second Circuit "identify which action or actions constituted the fraud and directly caused harm ... and then determine if that act or those actions emanated from the United States." 59

The Second Circuit ultimately found that subject matter jurisdiction was lacking. The court held that " $[\mathrm{t}]$ he actions taken and the actions not taken by [National] in Australia were . . . significantly more central to the fraud and more directly responsible for the harm to investors than the manipulation of the numbers in Florida." 60 The court concluded its opinion by acknowledging: "When a statement or public filing [made by National] fails to meet [applicable accounting, legal, and regulatory] standards, the responsibility, as a practical matter, lies in Australia, not Florida."61 Accordingly, the Second Circuit affirmed the dismissal of the appellants' claims for lack of subject matter jurisdiction.

In light of the uncertainty associated with the conduct test, the appellees invited the Second Circuit to adopt a bright-line rule regarding

53. $I d$. at $* 9$.

54. Morrison II, 547 F.3d at $169-70$.

55. Id.

56. Id. at 177 .

57. Id. at 168. After noting that the Exchange Act is silent with respect to its extraterritorial application, the Second Circuit "urge[d] that this significant omission receive the appropriate attention of Congress and the Securities and Exchange Commission." Id. at 170 n. 4 .

58. Id. at 176 .

59. Id. at 173 .

60. Id. at 176 .

61. Id. 
the extraterritorial reach of Section 10(b). ${ }^{62}$ The appellees argued that no amount of domestic conduct should be sufficient to confer subject matter jurisdiction if there was not some corresponding effect in the United States. $^{63}$ Because foreign-cubed cases, by definition, involve foreign investors suing foreign issuers in connection with securities transactions occurring on foreign exchanges, the relevant conduct in these cases does not have any U.S.-related effects. ${ }^{64}$ Consequently, under the appellees' proposed rule, foreign-cubed cases would be without the subject matter jurisdiction of U.S. courts.

The appellees asserted that such a rule would be consistent with the presumption against extraterritoriality, a canon of statutory construction providing that unless a contrary intent appears, U.S. laws are "meant to apply only within the territorial jurisdiction of the United States." ${ }^{\prime 65}$ Failure to adopt the appellees' proposed rule would allegedly "undermine the competitive and effective operation of American securities markets, discourage cross-border economic activity, . . . cause duplicative litigation[,]" and ensure international conflicts of law. ${ }^{66}$

The Second Circuit declined the appellees' invitation, stating: "[W]e are leery of rigid bright-line rules . ..."67 With respect to the appellees' conflicts of law concerns, the court declared:

The problem of conflict between our laws and those of a foreign government is much less of a concern when the issue is the enforcement of the anti-fraud sections of the securities laws than with such provisions as those requiring registration of persons or securities. The reason is that while registration requirements may widely vary, anti-fraud enforcement objectives are broadly similar as governments and other regulators are generally in agreement that fraud should be discouraged. ${ }^{68}$

The potential for conflict between Section 10(b) and the anti-fraud laws of foreign nations, thus, did not warrant abandoning the conduct and effects tests. $^{69}$

Moreover, the Second Circuit was concerned that the appellees' proposed rule would turn the United States into a "safe haven for securities cheaters" who would then export securities fraud to the rest of the world. ${ }^{70}$

62. Id. at 174

63. Id.

64. Id.

65. E.E.O.C. v. Arabian Am. Oil Co. (Aramco), 499 U.S. 244, 248 (1991) (quoting Foley Bros., Inc. v. Filardo, 336 U.S. 281, 285 (1949)).

66. Morrison II, 547 F.3d at 174.

67. Id. at 175 .

68. Id.

69. Id.

70. Id. 
The court conceded, however, that "we are an American court, not the world's court, and we cannot and should not expend our resources resolving cases that do not affect Americans or involve fraud emanating from America." 71 The conduct and effects tests were held to adequately balance these competing concerns such that the court declined to adopt the appellees' proposed rule. ${ }^{72}$

\section{The Supreme Court Opinion}

The question before the Supreme Court was "whether $\S 10(\mathrm{~b})$ of the Securities Exchange Act of 1934 provides a cause of action to foreign plaintiffs suing foreign and American defendants for misconduct in connection with securities traded on foreign exchanges." 73

The Court first addressed whether Section 10(b) applied extraterritorially. Justice Scalia noted that prior to 1968 the district courts in the Southern District of New York had consistently applied the presumption against extraterritoriality to hold that Section 10(b) did not reach fraud claims predicated on foreign stock transactions. ${ }^{74}$ Between 1968 and 1972, however, the Second Circuit "excised the presumption against extraterritoriality from the jurisprudence of $\S 10(\mathrm{~b}) \ldots . . ., 75$ Whereas the presumption against extraterritoriality provides that statutes should not be given extraterritorial effect absent a clear mandate from Congress, the Second Circuit had interpreted Congress' silence regarding the extraterritorial reach of Section 10(b) as an implied grant of authority to discern whether Congress would have wanted Section 10(b) to apply to a given fact pattern. $^{76}$ To facilitate this analysis, the Second Circuit developed the conduct and effects tests, which "became the north star of the Second Circuit's $\S 10(\mathrm{~b})$ jurisprudence, pointing the way to what

71. Id.

72. Id.

73. Morrison III, 130 S. Ct. at 2875. Justice Scalia, writing for the Court, held that the Southern District of New York erred in dismissing the petitioners' claims for lack of subject matter jurisdiction pursuant to Rule 12(b)(1) of the Federal Rules of Civil Procedure. Id. at 2877. Instead, the extraterritorial application of Section 10(b) was found to constitute a merits question properly reviewed under Rule 12(b)(6). Id. Nevertheless, the petitioners' request that the case be remanded to the Southern District of New York was denied on the grounds that "a remand would only require a new Rule 12(b)(6) label for the same Rule 12(b)(1) conclusion." Id. Consequently, the remainder of the Court's opinion addressed whether the petitioners' allegations stated a claim under the federal securities laws.

74. Id. at 2878 .

75. Id. at $2878-79$.

76. Id. at 2879. This analysis effectively turned the presumption against extraterritoriality on its head, requiring that Congress expressly disavow any extraterritorial application before the court would limit a statute's reach to domestic matters. 
Congress would have wished." 77

The Supreme Court criticized the conduct and effects tests on a number of grounds. First, the Second Circuit failed to identify "a textual or even extratextual [sic] basis for [the] tests." "78 Instead, as early as 1975 the Second Circuit conceded that, "if we were asked to point to language in the statutes, or even in the legislative history, that compelled these [tests], we would be unable to respond."

Second, the tests were difficult to administer. ${ }^{80}$ The conduct test varied depending on whether the harmed investors were Americans or foreigners, and satisfying the conduct test was not necessarily sufficient to confer subject matter jurisdiction since courts occasionally required that there be "some additional factor tipping the scales' in favor of the application of American law." " Justice Scalia declared, "[t]here is no more damning indictment of the 'conduct' and 'effects' tests than the Second Circuit's own declaration that 'the presence or absence of any single factor which was considered significant in other cases . . . is not necessarily dispositive in future cases." $" 82$

Third, variations of the conduct and effects tests had been adopted by the other circuits, resulting in an incoherent patchwork of tests for determining the extraterritorial application of Section $10(\mathrm{~b}) .^{83}$

Citing these failings, the Supreme Court rejected the conduct and effects tests in favor of a textual analysis of Section 10(b) as informed by the presumption against extraterritoriality ${ }^{84}$ After noting that "[o]n its face, $\S 10$ (b) contains nothing to suggest it applies abroad," Justice Scalia

77. Id.

78. $I d$.

79. Id. (quoting Bersch v. Drexel Firestone, Inc., 519 F.2d 974, 993 (2d Cir. 1975)).

80. Id.

81. Id. (quoting Interbrew v. Edperbrascan Corp., 23 F. Supp. 2d 425, 432 (S.D.N.Y. 1998)).

82. Id. (quoting I.I.T. v. Cornfeld, 619 F.2d 909, 918 (2d Cir. 1980)).

83. Id. at 2880. After quoting Justice Rehnquist's oft-cited declaration that "[w]hen we deal with private actions under Rule 10b-5, we deal with a judicial oak which has grown from little more than a legislative acorn," Justice Scalia noted that:

... [ $\mathrm{t}$ ]he concurrence seemingly believes that the Courts of Appeals have carefully trimmed and sculpted this "judicial oak" into a cohesive canopy, under the watchful eye of Judge Henry Friendly, the "master arborist." Even if one thinks that the "conduct" and "effects" tests are numbered among Judge Friendly's many fine contributions to the law, his successors, though perhaps under the impression that they nurture the same mighty oak, are in reality tending each its own botanically distinct tree.

Id. at 2880 n.4 (internal citations omitted).

84. See id. at 2881 ("The criticisms seem to us justified. The results of judicialspeculation-made-law - divining what Congress would have wanted if it had thought of the situation before the court-demonstrate the wisdom of the presumption against extraterritoriality."). 
proceeded to consider and reject three text-based arguments for the extraterritorial application of Section $10(\mathrm{~b}) .{ }^{85}$ First, the petitioners cited the Exchange Act's definition of "interstate commerce," a term used in Section 10(b), as evidence Congress intended to give the statute extraterritorial effect. $^{86}$ The Exchange Act defines "interstate commerce" to include "trade, commerce, transportation, or communication . . . between any foreign country and any State." ${ }^{87}$ The Court dismissed this argument, stating, "[W]e have repeatedly held that even statutes that contain broad language in their definitions of 'commerce' that expressly refer to 'foreign

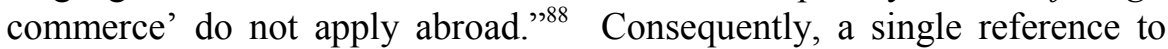
foreign commerce within a statutory definition was deemed insufficient to rebut the presumption against extraterritoriality. ${ }^{89}$

Next, the petitioners pointed to Congress' purpose in enacting the Exchange Act as evidence that Section 10(b) was meant to apply abroad. ${ }^{90}$ The prologue to the Exchange Act provides that "prices established and offered in such transactions are generally disseminated and quoted throughout the United States and foreign countries." 91 In rejecting this argument, the Supreme Court observed that the antecedent of "such transactions" was located "in the first sentence of the section, which declares that "transactions in securities as commonly conducted upon securities exchanges and over-the-counter markets are affected with a national public interest." 92 The Court concluded, "[n]othing suggests that this national public interest pertains to transactions conducted upon foreign exchanges and markets." 93

The petitioners' third and final text-based argument relied on Section 30(b) of the Exchange Act, which concerns persons "transact[ing] a business in securities without the jurisdiction of the United States." paraphrased by the Court, Section 30(b) provides:

"The provisions of [the Exchange Act] or of any rule or regulation thereunder shall not apply to any person insofar as he transacts a business in securities without the jurisdiction of the United States," unless he does so in violation of regulations promulgated by the Securities and Exchange Commission to

85. Id.

86. Id.

87. Id. at 2882 (quoting 15 U.S.C. $§ 78 c(17)$ (2010)).

88. Id. (quoting Aramco, 499 U.S. at 251) (emphasis in original).

89. Id.

90. Id.

91. Id. (quoting 15 U.S.C. $§ 78 \mathrm{~b}(2)$ (2010)).

92. Id. (quoting 15 U.S.C. $\S 78 \mathrm{~b}(2010)$ ).

93. Id. (emphasis in original).

94. 15 U.S.C. $\S 78 \mathrm{dd}(\mathrm{b})(2010)$. 
prevent . . evasion of [the Act]. ${ }^{95}$

The respondents argued that Section 30(b) "create[d] only a narrow, potential, SEC-gatekept extraterritorial application" of the Exchange Act that was insufficient by itself to rebut the presumption against extraterritoriality. ${ }^{96}$ In contrast, the United States Solicitor General argued that Section 30(b) confirmed the Exchange Act's extraterritorial effect because the "exemption" embodied in Section 30(b) "would have no function if the Act did not apply in the first instance to securities transactions that occur abroad." Solicitor General's proposed interpretation "possible," he held that "possible interpretations of statutory language do not override the presumption against extraterritoriality." 98

The petitioners' reliance on Section 30 (b) was further undercut by the text of Section 30(a). ${ }^{99}$ In relevant part, Section 30(a) provides:

It shall be unlawful for any broker or dealer . . . to make use of the mails or of any means or instrumentality of interstate commerce for the purpose of effecting on an exchange not within or subject to the jurisdiction of the United States, any transaction in any security the issuer of which is a resident of, or is organized under the laws of, or has its principal place of business in, a place within or subject to the jurisdiction of the United States, in contravention of such rules and regulations as the [Securities and Exchange] Commission may prescribe .... ${ }^{100}$

The Court found that Section "30(a) contains what $\S 10(\mathrm{~b})$ lacks: a clear statement of extraterritorial effect." $"$ Justice Scalia reasoned that this "explicit provision for a specific extraterritorial application would be quite superfluous if the rest of the Exchange Act already applied to transactions on foreign exchanges - and its limitation of that application to securities of domestic issuers would be inoperative."102 Consequently, the "clear statement" found in Section 30(a) confirmed that Congress knew how to give certain provisions of the Exchange Act extraterritorial effect such that the absence of similar language from Section 10(b) reflected a deliberate decision by Congress to limit its application to domestic securities

95. Morrison III, 130 S. Ct. at 2882 (quoting 15 U.S.C. $§ 78 d d(b)(2010)$ ).

96. Brief for Respondents at 54-55, Morrison III, 130 S. Ct. 2869 (2010) (No. 081191).

97. Brief for the United States as Amicus Curiae Supporting Respondents at 14, Morrison III, 130 S. Ct. 2869 (2010) (No. 08-1191).

98. Morrison III, 130 S. Ct. at 2883 (citing Aramco, 499 U.S. at 253).

99. Id.

100. Id. (quoting 15 U.S.C. $§ 78 d d(a)(2010)$ ).

101. Id.

102. Id. 
transactions. ${ }^{103}$

After concluding that Section 10(b) does not apply extraterritorially, the Court addressed the petitioners' argument that they were seeking only a domestic application of the Exchange Act. ${ }^{104}$ Emphasizing the extent of HomeSide's Florida-based activities, the petitioners asserted that the respondents' conduct was sufficiently domestic to state a claim under Section 10(b). ${ }^{105}$ Justice Scalia dismissed the petitioners' argument, reasoning that "the focus of the Exchange Act is not upon the place where the deception originated, but upon purchases and sales of securities in the United States." 106 He went on to note that "Section 10(b) does not punish deceptive conduct, but only deceptive conduct in connection with the purchase or sale of any security registered on a national securities exchange or any security not so registered." 107 Thus, even assuming that the conduct constituting the alleged fraud occurred entirely within the United States, the consolidated complaint failed to state a claim because the petitioners-all of whom were Australian-purchased their shares on the Australian Securities Exchange. ${ }^{108}$

The Court then announced a new "transactional test" for determining the reach of Section 10(b). ${ }^{109}$ The opinion contains three articulations of the test, each slightly different in its phrasing and terminology:

1. "And it is in our view only transactions in securities listed on domestic exchanges, and domestic transactions in other securities, to which $\S 10(\mathrm{~b})$ applies." 110

2. "[W]hether the purchase or sale is made in the United States, or involves a security listed on a domestic exchange ...."

3. "Section 10(b) reaches the use of a manipulative or deceptive device or contrivance only in connection with the purchase or sale of a security listed on an American stock exchange, and the purchase or sale of any other security in the United States." $" 12$

The Court asserted that its new test would avoid the international conflicts of law concerns raised by Australia, the United Kingdom, and France. ${ }^{113}$

103. Id.

104. $I d$. at $2883-86$.

105. Id. at $2883-84$.

106. Id. at 2884 .

107. Id. (quoting 15 U.S.C. $\S 78 \mathrm{j}(\mathrm{b})(2010)$ ).

108. Id. at $2884-88$.

109. Id. at 2886 .

110. Id. at 2884.

111. Id. at 2886 .

112. Id. at 2888 .

113. Id. at 2885-86. 
Applying the transactional test to the facts of Morrison, the Court held, "[t]his case involves no securities listed on a domestic exchange, and all aspects of the purchases complained of by those petitioners who still have live claims occurred outside the United States."114 Consequently, the Supreme Court affirmed the dismissal of the consolidated complaint pursuant to Federal Rule of Civil Procedure 12(b)(6). ${ }^{115}$

\section{F-SQUARED CASES POST-MORRISON}

Although meant to be a bright-line rule, the transactional test has proven difficult to administer for two reasons. First, the Supreme Court failed to provide a single, coherent articulation of the test. Instead, the opinion contains three variations of the test, each containing subtle yet potentially significant differences. Second, the various articulations are poorly drafted. ${ }^{116}$ The Court mistakes brevity for clarity, failing to define certain key terms or otherwise specify the precise contours of the test. Thus, rather than curing the uncertainty that plagued the conduct and effects tests, the transactional test has cast what was previously a semistable area of the law into abject confusion.

\section{A. F-Squared Plaintiffs' Attempts to Circumvent Morrison}

Plaintiffs seeking to preserve f-squared claims argue that Morrison should be limited to its facts so that only f-cubed cases are outside the scope of Section 10(b). They contend that Morrison's holding turned on the fact that "all aspects of the purchases complained of . . . occurred outside the United States" such that "the Supreme Court did not addressand did not foreclose - the claims of U.S. investors who purchased securities on a foreign exchange, where 'aspects of the purchase' occurred in the United States." 117

114. Id. at 2888 .

115. Id.

116. Richard Painter et al., When Courts and Congress Don't Say What They Mean: Initial Reactions to Morrison v. National Australia Bank and to the Extraterritorial Jurisdiction Provisions of the Dodd-Frank Act, 20 MINN. J. INT'L L. 1, 8-14 (2011).

117. Supplemental Memorandum of Law Addressing Morrison v. National Australia Bank Ltd. and in Further Support of the Motion of the U.S. Members of the Institutional Investor Group for Appointment as Lead Plaintiff at 2-3, Stackhouse v. Toyota Motor Corp., 2010 WL 3377409 (C.D. Cal. 2010) (No. 10-922) (quoting Morrison III, 130 S. Ct. at 2888) (emphasis added); see also Plaintiffs' Supplemental Memorandum Concerning the Impact of Morrison v. National Australia Bank at 5, In re Vivendi Universal, S.A. Sec. Litig., 765 F. Supp. 2d 512 (S.D.N.Y. 2011) (No. 02-5571) ("Unlike the facts of Morrison, this is not a situation where 'all aspects of the purchases . . . occurred outside the United States.'”); Lead Plaintiffs Massachusetts Pension Reserves Investment Management Board and Mississippi Public Employees' Retirement System's Supplemental Memorandum of 
Plaintiffs ostensibly find support for their "some domestic aspects" argument in the text of the transactional test. While conceding that securities listed exclusively on foreign exchanges cannot satisfy the "securities listed on domestic exchanges" prong of the test, f-squared plaintiffs contend that transactions in such securities may nevertheless qualify as "domestic transactions in other securities" so long as aspects of the transactions occur in the United States.

By focusing on the purportedly domestic aspects of their purchases, fsquared plaintiffs seek to replace the Court's bright-line rule with a factintensive inquiry reminiscent of the conduct and effects tests. Consider, for example, the arguments put forth by the plaintiff - a U.S. institutional investor - in the Swiss Reinsurance Company securities fraud class action litigation. ${ }^{118}$ There, the plaintiff asserted that its purchases of Swiss Re stock on the Swiss stock exchange constituted "domestic transactions" within the meaning of the transactional test because the plaintiff "made the decision to invest in Swiss Re stock, and initiated the purchase of Swiss Re stock, from the United States." 119 In support of its contention, the Swiss Re plaintiff cited the following facts:

As set forth in the accompanying affidavit of Tremaine Atkinson, the Chief Operating Officer at LSV Asset Management ("LSV"), the Chicago-based brokerage firm authorized to make trades on behalf of [the plaintiff] during the Class Period, the decision to purchase Swiss Re stock on behalf of [the plaintiff] was made by LSV portfolio managers located in Chicago. Then, Chicagobased traders at LSV electronically placed orders for Swiss Re stock on behalf of [the plaintiff]. Those purchase orders were then executed by LSV traders located in Chicago, who electronically routed the orders through electronic connections

Law Addressing the Impact of Morrison v. National Australia Bank Ltd. at 6, In re Royal Bank of Scot. Group PLC Sec. Litig., 765 F. Supp. 2d 327 (S.D.N.Y. 2011) (No. 09-300) [hereinafter RBS Plaintiffs' Memorandum of Law] ("Unlike the situation in Morrison where the plaintiffs were 'all Australians' and 'all aspects of the purchases took place outside the United States,' here the purchases occurred within the United States . . . ."); Plaintiff's Memorandum of Law in Opposition to Defendants' Supplemental Memorandum of Law in Further Support of Their Motion to Dismiss the Second Amended Complaint at 4, Plumbers' Union Local No. 12 Pension Fund v. Swiss Reinsurance Co., 753 F. Supp. 2d 166 (S.D.N.Y. 2010) (No. 08-1958) [hereinafter Swiss Reinsurance Plaintiff's Memorandum of Law] ("Morrison clearly contemplated circumstances where $§ 10$ (b) was implicated by the occurrence of only some 'aspect' of a securities transaction within the U.S.") (emphasis in original); Memorandum in Support of Plaintiffs' Motion for Reconsideration of Dismissal of LAMPERS' Claims or to Certify Dismissal at 3 n.2, Cornwell v. Credit Suisse Group, 729 F. Supp. 2d 620 (S.D.N.Y. 2010) (No. 08-3758) ("The analysis of 'all aspects of the purchases' does not make sense if only one 'aspect,' where the securities transaction was recorded, was controlling.").

118. Swiss Reinsurance Plaintiff's Memorandum of Law, supra note 117, at 2.

119. Id. at 7 . 
that LSV maintains with a number of brokers who are responsible for matching purchase orders for Swiss Re stock with shares of Swiss Re stock that are offered for sale. In sum, Mr. Atkinson averred that: (i) the decision to purchase Swiss Re Stock [sic] was made by LSV portfolio managers in Chicago; (ii) the orders for Swiss Re stock were placed from Chicago; and (iii) the LSV traders who executed the purchase orders for Swiss Re stock were located in Chicago. ${ }^{120}$

The Swiss Re plaintiff, thus, argued that the domestic aspects of its purchases rendered them distinguishable from the wholly-foreign purchases at issue in Morrison. ${ }^{121}$ Plaintiffs in other f-squared cases have advanced similar arguments. ${ }^{122}$

F-squared defendants have had no choice but to respond in kind and list every conceivable fact demonstrating the foreign nature of the underlying securities transactions. Again, the Swiss Re case is illustrative. After noting that the judge had "repeatedly urged Plaintiff to submit an

120. Id. at 7-8 (internal citations omitted).

121. See id. at $1-5$.

122. See Cornwell v. Credit Suisse Group, 729 F. Supp. 2d 620, 622 (S.D.N.Y. 2010) (arguing plaintiffs "made an investment decision and initiated a purchase of [Credit Suisse] stock from the U.S." and "took the [Credit Suisse] stock into its own account in the U.S. and incurred an economic risk in the U.S."); Massachusetts Pension Reserves Investment Management Board's Supplemental Memorandum Addressing Morrison v. National Australia Bank and in Further Support of its Motion for Appointment as Lead Plaintiff and Selection of Lead Counsel at 3-4, Stackhouse v. Toyota Motor Corp., 2010 WL 3377409 (C.D. Cal. 2010) (No. 10-00922) (contending that the location "where the investment decision is made" is dispositive of whether the transaction is foreign or domestic such that plaintiff's decision "to purchase its Toyota stock occurred within the U.S., as virtually all of its money managers are U.S. based"); Plaintiffs' Sur-Reply Addressing the Impact of Morrison v. National Australia Bank and Reply in Support of Plaintiffs' Motion for Leave to Take Personal Jurisdiction Discovery at 5, In re Société Générale Sec. Litig., 2010 WL 3910286 (S.D.N.Y. 2010) (No. 08-02495) (arguing that one plaintiff "did not leave the United States to purchase SocGen stock" but instead acquired the security "by means of domestic contractual transactions, through U.S. investment managers"); Lead Plaintiffs' Letter-Brief Responding to Show Cause Order as to Why the Federal Securities Claims of Plaintiffs Who Purchased Alstom S.A. Securities that are Recorded on Exchanges Located Outside the U.S. Should Not be Dismissed in Light of Morrison v. National Australia Bank Ltd. at 3, In re Alstom SA Sec. Litig., 741 F. Supp. 2d 469 (S.D.N.Y. 2010) (No. 03-6595) (asserting that "[a]11 of the Lead Plaintiffs' transactions were initiated in the U.S. and, as a result, amount to 'the purchase or sale' of a security 'in the United States'"); Lead Plaintiffs' Memorandum of Law in Opposition to UBS Defendants' Motion to Dismiss Claims Based on Purchases of UBS Shares Outside the United States at 33-35, In re UBS AG Sec. Litig. (S.D.N.Y. Oct. 18, 2010) (No. 07-11225) ("Oregon's purchase of UBS stock occurred in the U.S. . . because Oregon made the decision to invest in UBS stock, and initiated the purchase of UBS stock, from the U.S. by means of domestic contractual transactions."); RBS Plaintiffs' Memorandum of Law, supra note 117, at 7 (asserting plaintiffs were "prepared to demonstrate that their decisions to purchase many of their RBS ordinary shares were made in the United States, based on the direction of their United States-based asset managers"). 
affidavit setting out the full details of its stock transactions," the defendants suggested that the court had received only half of the picture. ${ }^{123}$ Specifically, the defendants asserted that the plaintiff's affidavit was "silent regarding what happened after LSV placed the orders-where the orders were sent or where the trades were executed, cleared and settled." ${ }^{124}$ In an attempt to fill in the missing pieces, the defendants cited the following facts:

In $2007 \ldots$. Swiss Re common stock was listed only on the SWX Swiss Exchange ... and was traded only on virt-x[,] . . a subsidiary of SWX Swiss Exchange based in London. All market transactions in Swiss Re common stock during the purported class period were executed, cleared and settled on virt$\mathrm{x}$ 's trading platform in Europe.

Specifically, all clearing services for virt-x . . . were performed by either LCH.Clearnet Ltd or SIS x-clear Ltd. LCH.Clearnet Ltd maintains its registered office in London. SIS $\mathrm{x}$-clear Ltd. . . . is a Zurich based company and part of the SIS Swiss Financial Services Group AG.

All settlement services for virt-x trades were performed by Euroclear UK \& Ireland Ltd, SIS SegaInterSettle AG or Euroclear Bank. Euroclear UK \& Ireland Ltd is incorporated in England and Wales and maintains a registered office in London. SIS SegaInterSettle AG is an Olten, Switzerland based company and part of the SIS Swiss Financial Services Group AG. Euroclear Bank is a limited liability company incorporated and domiciled in Belgium. ${ }^{125}$

The defendants asserted that although the investment decisions and purchase orders may have originated in Chicago, the trades were actually executed, cleared, and settled in Europe such that they constituted foreign transactions outside the scope of Section 10(b). ${ }^{126}$

The Swiss Re case, thus, illustrates precisely the sort of subjective, fact-intensive inquiry the Supreme Court sought to avoid in announcing its new transactional test. ${ }^{127}$ If lower courts were to hold that Section 10 (b)

123. Supplemental Reply Memorandum of Law in Further Support of Defendants' Motion to Dismiss Plaintiff's Second Amended Complaint at 5, Plumbers' Union Local No. 12 Pension Fund v. Swiss Reinsurance Co., 753 F. Supp. 2d 166 (S.D.N.Y. 2010) (No. 0801958).

124. Id.

125. Id. at 5-6 (internal citations omitted).

126. Id. at 5-9.

127. See Credit Suisse, 729 F. Supp. 2d at 624 (rejecting plaintiffs" "some domestic aspects" argument on the ground that "[t]he creation of such an exception to the Morrison transactional rule necessarily would invite extensive analysis required to parse foreign securities trades so as to assess quantitatively how many and which parts or events of the 
applies whenever the underlying securities transaction has "some domestic aspects," this sort of analysis would be required in virtually every f-squared case.

\section{B. Lower Courts'Application of the Transactional Test}

As of the date of publication, no court had been persuaded by the "some domestic aspects" interpretation of the transactional test. In dismissing f-squared claims, however, district courts have ignored arguably the simplest and most direct means for disposing of these cases.

Consider, for example, the case of Cornwell v. Credit Suisse Group. ${ }^{128}$ Approximately two weeks after the Supreme Court handed down its opinion in Morrison, the Credit Suisse defendants moved for judgment on the pleadings with respect to those plaintiffs who purchased Credit Suisse shares on the Swiss Stock Exchange. ${ }^{129}$ In granting the defendants' motion, Judge Victor Marrero relied on the Morrison Court's rationale and policy objectives rather than on the text of the transactional test. ${ }^{130}$

Judge Marrero predicated his dismissal of the plaintiffs' f-squared claims on three grounds. ${ }^{131}$ First, the "some domestic aspects" interpretation of the transactional test improperly sought to revive the conduct and effects tests. Second, under the plaintiffs' theory, U.S. courts "would be called upon to enforce American laws regulating transactions in securities that are also governed by the laws of the foreign country and exchanges where those securities were actually purchased or sold" in contravention of Morrison. ${ }^{132}$ Third, the Supreme Court had signaled that semi-domestic securities transactions would not satisfy the transactional test. $^{133}$

For Judge Marrero, the Morrison Court's citation to Aramco ${ }^{134}$ provided additional evidence "that the presumption against extraterritorial effect should not be diminished just because 'some domestic activity is involved in the case." "135 In Aramco, the Supreme Court affirmed the

\footnotetext{
transactions occurred within United States territory, and then to apply value judgments to determine whether the cluster of those activities sufficed to cross over the threshold of enough domestic contacts to justify extraterritorial application of $\S 10(\mathrm{~b})$ "); see also Plumbers' Union Local No. 12 Pension Fund v. Swiss Reinsurance Co., 753 F. Supp. 2d 166, 178 (S.D.N.Y. 2010) (noting that "[t]he plaintiffs' construction would require a factbound, case-by-case inquiry").

128. 729 F. Supp. 2d 620 (S.D.N.Y. 2010).

129. Id. at 621 .

130. Id.

131. Id. at 624.

132. Id. at 625 .

133. Id.

134. Aramco, 499 U.S. at 244.

135. Credit Suisse, 729 F. Supp. 2d at 626 (quoting Morrison III, 130 S. Ct. at 2884).
} 
dismissal of a lawsuit brought by an American citizen against two of his former employers, both Delaware corporations, for discriminatory conduct that allegedly occurred while the plaintiff was working for the defendants in Saudi Arabia. ${ }^{136}$ After concluding that the Civil Rights Act of 1964 did not apply extraterritorially, the Supreme Court held that dismissal was warranted even though the plaintiff was a U.S. citizen and had been hired by the defendants in Houston, Texas. ${ }^{137}$ Consequently, Judge Marrero concluded that securities transactions may have some domestic aspects and still be outside the scope of Section 10(b). ${ }^{138}$

Thus, rather than relying solely on the text of the transactional test to hold that the defendants were entitled to judgment on the pleadings vis-àvis those plaintiffs who purchased Credit Suisse shares on the Swiss Stock Exchange, Judge Marrero instead engaged in an unnecessarily protracted analysis of the Morrison Court's rationale and policy objectives. ${ }^{139}$

Several weeks later, Judge Marrero dismissed the claims of another fsquared plaintiff in an unrelated case, relying solely on his opinion in Credit Suisse. ${ }^{140}$ Other judges have similarly relied on Credit Suisse to dismiss f-squared plaintiffs' claims — often without articulating any independent rationale of their own. ${ }^{141}$

Swiss Re is another example of an f-squared case in which the court failed to identify the most direct, text-based rationale for dismissing the plaintiff's claims. Judge Koeltl of the United States District Court for the Southern District of New York phrased the issue as follows: "Whether a

136. Aramco, 499 U.S. at 247.

137. Id.

138. Credit Suisse, 729 F. Supp. $2 \mathrm{~d}$ at 626. In a footnote, Judge Marrero asserted that Justice Stevens' concurrence provided additional evidence that f-squared claims are outside the scope of Section 10(b) post-Morrison. Specifically, Justice Stevens indicated that the transactional test would not be satisfied under the following fact pattern: "[A]n American investor . . . buys shares in a company listed only on an overseas exchange" and "[t]hat company has a major American subsidiary with executives based in New York City; and it was in New York City that the executives masterminded and implemented a massive deception which artificially inflated the stock price . . ." Id. at 627 (quoting Morrison III, 130 S. Ct. at 2895).

139. Id. at 625-27; see also In re Vivendi Universal, S.A. Sec. Litig., 765 F. Supp. 2d 512, 532-34 (S.D.N.Y. 2011) (relying on Aramco and Justice Stevens' concurrence in Morrison to dismiss f-squared claims).

140. See In re Alstom SA Sec. Litig., 741 F. Supp. 2d 469, 472 (S.D.N.Y. 2010) ("In [Credit Suisse], this Court rejected Plaintiffs' first contention [- that a U.S. investor's purchase of foreign securities on a foreign exchange constitutes a domestic transaction under Morrison because the purchase was initiated in the United States-] as a general matter.").

141. See In re Royal Bank of Scot. Group PLC Sec. Litig., 765 F. Supp. 2d 327, 336 (S.D.N.Y. 2011) (quoting the transactional test and citing Judge Marrero's holding in Credit Suisse); Sgalambo v. McKenzie, 739 F. Supp. 2d 453, 487 (S.D.N.Y. 2010) (quoting the transactional test and citing Judge Marrero's holding in Credit Suisse). 
security that is not traded on a domestic stock exchange is 'purchase[d] . . . in the United States' for the purposes of section 10(b) any time an investor decides to purchase the security and places a purchase order with a broker while in the United States." 142 After noting that the Supreme Court "did not have occasion to discuss what it means for a purchase or sale to be "made in the United States[,]"' Judge Koeltl acknowledged that the Court "did, however, make it clear that that question is guided by the text of the Exchange Act and by the need to adopt clear tests that avoid interference with foreign securities regulation."

The Exchange Act defines the term "purchase" to include "any contract to buy, purchase, or otherwise acquire." "144 Citing Second Circuit precedent, the Swiss Re plaintiff argued that an individual becomes a purchaser within the meaning of the Exchange Act "when he or she incur[s] an irrevocable liability to take and pay for the stock," i.e., at the moment the investor places a buy order. ${ }^{145}$ Because the relevant buy orders were placed by brokers located in Chicago, the plaintiff asserted that its purchases of Swiss Re common stock occurred in the U.S. ${ }^{146}$ Judge Koeltl noted that other courts considering f-squared claims had "unanimously rejected" this argument and reasoned that the term "purchase" must be construed so as to avoid the international conflicts of law concerns raised in Morrison. ${ }^{147}$ Consequently, the court held that "as a general matter, a purchase order in the United States for a security that is sold on a foreign exchange is insufficient to subject the purchase to the coverage of section 10(b) of the Exchange Act." 148

After finding that the trades were executed, cleared, and settled in Europe, Judge Koeltl proceeded to reject the plaintiff's arguments that these were nevertheless domestic securities transactions within the scope of Section 10(b). First, the court held that the plaintiff's status as a U.S. resident was irrelevant: “A purchaser's citizenship or residency does not affect where a transaction occurs; a foreign resident can make a purchase within the United States, and a United States resident can make a purchase outside the United States." " was made in Chicago had "no bearing on where the stock was ultimately

142. Plumbers' Union Local No. 12 Pension Fund v. Swiss Reinsurance Co., 753 F. Supp. 2d 166, 175-76 (S.D.N.Y. 2010) (citations omitted).

143. Id. at 176 (quotation marks omitted).

144. Id. at 177 (quoting 15 U.S.C. § 78c(a)(13) (2010)).

145. Id. (citing Blau v. Ogsbury, 210 F.2d 426, 427 (2d Cir. 1954)).

146. Id.

147. See id. (stating that the term "'purchase' cannot bear the expansive construction plaintiffs propose, at least for the purposes of Morrison's transactional test").

148. Id. at 178.

149. Id. 
purchased."150 Third, although the plaintiff may have suffered financial harm in the U.S., "the location of the harm . . . is independent of the location of the securities transaction that produced the harm." 151 Fourth, it was deemed immaterial that the purchase orders were placed and executed in Chicago. ${ }^{152}$ The plaintiff's claims were therefore dismissed for failing to satisfy the transactional test. ${ }^{153}$

\section{A TeXt-Based Rationale For Dismissing F-SQUared Claims}

Although courts considering f-squared claims post-Morrison arguably have reached the correct result, the means by which they have arrived at their holdings has, to date, been unnecessarily protracted and circuitous. Rather than relying on the Supreme Court's policy objectives in announcing its new test or attempting to divine the Court's intentions from Justice Stevens' concurrence, courts confronted with f-squared claims should look first to the text of the transactional test itself. As noted previously, the Morrison Court provided three articulations of the test:

1. "And it is in our view only transactions in securities listed on domestic exchanges, and domestic transactions in other securities, to which § 10(b) applies."

2. "[W]hether the purchase or sale is made in the United States, or involves a security listed on a domestic exchange . . .."155

3. "Section 10(b) reaches the use of a manipulative or deceptive device or contrivance only in connection with the purchase or sale of a security listed on an American stock exchange, and the purchase or sale of any other security in the United States."

Although worded slightly differently, each articulation of the test was meant to track the language of Section 10(b), which prohibits deceptive conduct "in connection with the purchase or sale of any security registered on a national securities exchange or any security not so registered." 157 Whereas the Second Circuit had been unable to identify a textual or even extra-textual basis for the conduct and effects tests, the Morrison Court was careful to note the transactional test's textual origin: ${ }^{158}$

150. Id.

151. Id.

152. Id. at 177 .

153. Id.

154. Morrison III, 130 S. Ct. at 2884.

155. Id. at 2886.

156. Id. at 2888 .

157. 15 U.S.C. $\S 78 \mathrm{j}(\mathrm{b})(2010)$

158. See John C. Coffee, Jr., What Hath Morrison Wrought?, N.Y. L.J., Sept. 16, 2010, at 5 ("Morrison is a decision that rests at least as much on a close reading of the statutory 
Section 10(b) does not punish deceptive conduct, but only deceptive conduct "in connection with the purchase or sale of any security registered on a national securities exchange or any security not so registered." Those purchase-and-sale transactions are the objects of the statute's solicitude. It is those transactions that the statute seeks to "regulate[;]" it is parties or prospective parties to those transactions that the statute seeks to "protect." And it is in our view only transactions in securities listed on domestic exchanges, and domestic transactions in other securities, to which $\S 10(\mathrm{~b})$ applies. ${ }^{159}$

In announcing the transactional test, Justice Scalia sought to justify his use of the term "listed" rather than "registered" by noting that the Exchange Act's "registration requirements apply only to securities listed on national securities exchanges."

The transactional test's basis in the text of Section 10(b) has significant implications for plaintiffs seeking to assert f-squared claims. Specifically, if the "transactions in securities listed on domestic exchanges" prong of the test corresponds to the "purchase or sale of any security registered on a national securities exchange" provision of Section 10(b), then the "domestic transactions in other securities" prong of the test necessarily corresponds to the "any security not so registered" provision of the statute. Consequently, Congress's motivation for including the phrase "any security not so registered" in the text of Section 10(b) is directly relevant to how lower courts interpret the "domestic transactions in other securities" prong of the transactional test.

The Exchange Act's legislative history reveals that Congress included the phrase "any security not so registered" to provide for the regulation of the domestic over-the-counter markets, not foreign securities exchanges. ${ }^{161}$ As originally drafted, the Act regulated only purchases and sales of registered securities. ${ }^{162}$ The phrase "any security not so registered" was subsequently added to prevent a large-scale exodus from the national

text as on the presumption against extraterritoriality."); see also George T. Conway, III, Postscript to Morrison v. National Australia Bank, N.Y. L.J., Oct. 14, 2010, at 5 (acknowledging that the transactional test's "reference to 'the purchase or sale of a security listed on an American stock exchange' - derives from $\S 10(\mathrm{~b})$ 's reference to 'the purchase or sale of any security registered on a national securities exchange"').

159. Morrison III, 130 S. Ct. at 2884 (citations omitted) (emphasis added).

160. Id. at 2885 .

161. See generally Randall W. Quinn, The Supreme Court's Use of Legislative History in Interpreting the Federal Securities Laws, 22 SEC. REG. L.J. 262, 276 (1994) (asserting that "[a]s to the securities laws specifically, legislative history provides an invaluable context for judicial interpretation").

162. Steve Thel, The Original Conception of Section 10(b) of the Securities Exchange Act, 42 StAN. L. ReV. 385, 426-28, 443-44 (1990). 
securities exchanges. ${ }^{163}$ Congress feared that if the Act's scope was limited to registered securities, companies would de-list from the national exchanges in favor of selling their securities in the over-the-counter markets. ${ }^{164}$ The inclusion of the phrase "any security not so registered" was designed to remove this incentive by bringing the over-the-counter markets within the purview of the Exchange Act. ${ }^{165}$

The statutory text confirms that regulation of the domestic over-thecounter markets was a key objective of the Seventy-Third Congress. The Exchange Act's prologue acknowledges that "transactions in securities as commonly conducted upon securities exchanges and over-the-counter markets are affected with a national public interest which makes it necessary to provide for regulation and control of such transactions." ${ }^{166}$ According to the Act, the need for regulation stemmed from the fact that (1) "[transactions in securities as commonly conducted upon securities exchanges and over-the-counter markets] . . . in large part originate outside the States in which the exchanges and over-the-counter markets are located[;]" (2) "[t]he prices established and offered in such transactions are generally disseminated and quoted throughout the United States and foreign countries[;]" and (3) "[f]requently the prices of securities on such exchanges and [over-the-counter] markets are susceptible to manipulation and control." 167

The United States Supreme Court has likewise recognized that " $[t]$ he 1934 Act was intended principally to protect investors against manipulation of stock prices through regulation of transactions upon securities exchanges and in over-the-counter markets." $" 168$

Thus, for the purposes of the transactional test, the most logical reading of the phrase "domestic transactions in other securities" is "transactions in the domestic over-the-counter market."169 This distinction

163. Id. at 443,444 n.263.

164. Stock Exchange Practices: Hearings on S. Res. 84, S. Res. 56 and S. Res. 97 before the Comm. on Banking and Currency, 73d Cong. 6495-96, 6539-41, 6547-49, 6554-55, 6699 (1934) [hereinafter Hearings], reprinted in 6 and 7 Legislative History OF THE Securities ACt of 1933 And Securities Exchange ACt of 1934, Item 22 (J.S. Ellenberger \& Ellen P. Mahar eds., 1973) [hereinafter LegisLative History]; H.R. REP. No. 73-1383, at 15-16 (1934), reprinted in 5 Legislative History, Item 18; S. ReP. No. 73-792, at 5-6 (1934), reprinted in 5 LEGISLATIVE HISTORY, Item 17.

165. Hearings, supra note 164, Item 22; H.R. REP. No. 73-1383, supra note 164, Item 18, at $22-23$.

166. 15 U.S.C. $\S 78 b$ (2010). According to Justice Scalia, "[n]othing suggests that this national public interest pertains to transactions conducted upon foreign exchanges and markets." Morrison III, 130 S. Ct. at 2882 (emphasis in original).

167. 15 U.S.C. $\S 78 b(2010)$.

168. Ernst \& Ernst v. Hochfelder, 425 U.S. 185, 195 (1976).

169. See Vivendi, S.A.'s Supplemental Memorandum of Law Regarding the Supreme Court's Decision in Morrison v. National Australia Bank Ltd. at 5 n.2, In re Vivendi 
is significant to the extent it excludes transactions conducted on exchange markets from the "domestic transactions in other securities" prong of the transactional test. Whereas exchange markets are "auction markets where the orders of buyers and sellers are concentrated for the purpose of offering transactions through the meeting of the highest bid and the lowest offer," 170 "the over-the-counter market is a negotiated market in which . . . dealers acting as principals buy from and sell to investors or other dealers at an undisclosed profit."171 Consequently, U.S. investors' purchase of securities on foreign exchanges would not qualify as "transactions in the domestic over-the-counter market" under the proposed reading of the transactional test.

This text-based rationale arguably provides the simplest, most direct means for disposing of f-squared claims post-Morrison. Had the Supreme Court simply affirmed the dismissal of the Australian Plaintiffs' claims without bothering to articulate a new test for determining the scope of Section 10(b), lower courts would be justified in relying on the rationale underlying the Morrison Court's holding. In announcing the transactional test, however, the Supreme Court sought to limit lower courts' analyses to whether the relevant transactions involved a security listed on a domestic stock exchange or traded in the domestic over-the-counter market. To date, the construction advocated in this Article represents the only text-based rationale for dismissing f-squared claims under the transactional test.

\section{IMPLICATIONS OF THE NEWLY-CLARIFIED TRANSACTIONAL TEST}

As demonstrated in Section IV, supra, securities transactions in the domestic over-the-counter market remain subject to the antifraud

Universal, S.A. Sec. Litig., 765 F. Supp. 2d 512 (S.D.N.Y. 2011) ("The phrase 'purchase or sale of any other security in the United States' . . . plainly refers only to purchases of unregistered securities ... ."); The Royal Bank of Scotland Group PLC's Supplemental Memorandum of Law Addressing the Impact of Morrison v. National Australia Bank Ltd. on its Pending Motions to Dismiss at 10 n.7, In re Royal Bank of Scot. Group PLC Sec. Litig., 765 F. Supp. 2d 327 (S.D.N.Y. 2011) ("The [Morrison] Court's statement that the Exchange Act applies to 'domestic transactions in other securities' besides those listed in the United States appears to refer to domestic transactions in unlisted securities (e.g., overthe-counter securities that do not qualify for listing on a domestic exchange), as opposed to securities listed on foreign exchanges.”); see also Lancer Mgmt. Group LLC v. Lauer, No. 05-60584, 2011 WL 573954, at *1 (S.D. Fla. Feb. 15, 2011) (finding Morrison distinguishable where the relevant entities "traded substantial securities on U.S. exchanges [and] over-the-counter markets"); Stackhouse v. Toyota Motor Corp., 2010 WL 3377409, at *1 (C.D. Cal. 2010) (holding that "“domestic transactions' or 'purchases or sales in the United States' means purchases and sales of securities explicitly solicited by the issuer within the United States rather than transactions in foreign-traded securities").

170. Brief for Petitioners at 15 n.7, Silver v. N.Y. Stock Exch., 373 U.S. 341 (1963) (No. $150)$.

171. Id. at 15 . 
provisions of Section 10(b) under the Supreme Court's new transactional test. Post-Morrison, however, some lower courts have shown a willingness to dismiss securities fraud claims predicated on OTC transactions. ${ }^{172}$ Not surprisingly, the merits of these holdings appear dubious when analyzed in light of the newly-clarified transactional test.

Consider, for example, the securities fraud class action lawsuit brought against Société Générale ("SocGen") ${ }^{173}$ following the collapse of the subprime mortgage market. ${ }^{174}$ There, two of the three named plaintiffs ("Ordinary Share Plaintiffs") 175 were U.S. investors who purchased SocGen's ordinary shares on the Euronext Paris stock exchange. ${ }^{176}$ The third named plaintiff (“ADR Plaintiff") ${ }^{177}$ was a U.S. investor who purchased SocGen ADRs in the domestic over-the-counter market. ${ }^{178}$ While conceding that the ADR Plaintiff's claims remained viable postMorrison, the defendants moved to dismiss the Ordinary Share Plaintiffs' claims on the ground they ran afoul of the transactional test. ${ }^{179}$ To the parties' surprise, the judge dismissed all three of the named plaintiffs' claims based solely on Morrison. ${ }^{180}$

Significantly, in evaluating the ADR Plaintiff's claims, the judge ignored the transactional test altogether. Instead, dismissal was predicated on the court's characterization of ADR trades as "predominantly foreign securities transaction[s]." " For support, the court cited to a single, preMorrison opinion applying the now defunct conduct and effects tests. ${ }^{182}$

172. Such holdings were foreseeable given the Supreme Court's failure, in announcing the transactional test, to reference the over-the-counter market explicitly or otherwise specify the circumstances under which a transaction will be deemed to have occurred in the domestic over-the-counter market.

173. In re Société Générale Sec. Litig., No. 08 Civ. 2495, 2010 WL 3910286, at *1 (S.D.N.Y. Sept. 29, 2010).

174. Id.

175. The Ordinary Share Plaintiffs were Vermont Pension Investment Committee and Boilermaker-Blacksmith National Pension Fund. Id.

176. Id.

177. The ADR Plaintiff was United Food and Commercial Workers Union Local 880 Retail Food Employers Joint Pension Fund. Id.

178. Id.

179. Id. at $* 5-* 6$.

180. Id. at $* 5-* 7$.

181. $I d$. at $* 6$.

182. Id. (citing Copeland v. Fortis, 685 F. Supp. 2d 498 (S.D.N.Y. 2010)). Copeland, in turn, cites to In re SCOR Holding (Switzerland) AG Litigation for the proposition that "[t]rade in ADRs is considered to be a predominately foreign securities transaction." Copeland, 685 F. Supp. 2d at 506 (citing In re SCOR Holding (Switzerland) AG Litig., 537 F. Supp. 2d 556 (S.D.N.Y. 2008)). However, the court in SCOR Holding did not rule that ADR trades are predominately foreign securities transactions but instead simply assumed so for the sake of applying the effects test. SCOR Holding, 537 F. Supp. 2d at 561. Moreover, in SCOR Holding the court ultimately determined that it possessed subject matter jurisdiction "over the claims of any person who purchased . . ADSs on the NYSE." Id. at 
Moreover, the judge incorrectly asserted that dismissal of the ADR Plaintiff's claims was supported by Credit Suisse. ${ }^{183}$ In Credit Suisse, however, Judge Marrero's dismissal order was limited to claims brought by investors who purchased Credit Suisse shares on the Swiss Stock Exchange, and the claims of investors who purchased ADRs on the New York Stock Exchange were allowed to proceed. ${ }^{184}$

The authority relied upon by the judge, thus, did not support dismissal of the ADR Plaintiff's claims. Although the ruling is arguably ripe for reversal as a result, had the court undertaken a text-based analysis of the transactional test, the error of its reasoning would have been plain. Application of the transactional test would have revealed that the ADR Plaintiff's claims necessarily survive post-Morrison for the simple reason that they are predicated on securities transactions in the domestic over-thecounter market.

Another opinion that is questionable in light of the newly-clarified transactional test is Absolute Activist Value Master Fund Ltd. v. Homm. ${ }^{185}$ In that case, a group of Cayman Island based hedge funds ("Funds") ${ }^{186}$ claimed to be the victims of a pump-and-dump scheme orchestrated by certain defendants, including the Funds' Europe-based investment manager. ${ }^{187}$ According to the amended complaint, the scheme worked as follows: After obtaining control of a dormant or near dormant shell company, the defendants would cause one or more of the Funds to purchase a subscription for the company's shares. ${ }^{188}$ The defendants, meanwhile, would already own large quantities of the company's shares or have the company issue shares and warrants to them in exchange for arranging the Funds' purchases. ${ }^{189}$ Thereafter, the defendants would cause the Funds to trade and re-trade "the stocks many times over, sometimes on the same day, between and among [themselves]" in order to inflate the stocks' price

560 n.3.

183. Société Générale, 2010 WL 3910286, at *6 n.5.

184. Cornwell v. Credit Suisse Group, 729 F. Supp. 2d 620, 622, 629 (S.D.N.Y. 2010). The SocGen court rejected the Ordinary Share Plaintiffs' argument that because they were U.S. investors who placed their buy orders through U.S.-based investment managers, their purchases constituted domestic transactions within the meaning of the transactional test. Société Générale, 2010 WL 3910286, at *5-*6. However, like the cases discussed in Section III(B), supra, the SocGen judge did not base his decision on the text of the transactional test but instead relied on Judge Marrero's holding in Credit Suisse and the Morrison Court's damning indictment of the conduct and effects tests to conclude that dismissal of the Ordinary Share Plaintiffs' claims was warranted. See id.

185. No. 09 CV 8862, 2010 WL 5415885, at*1 (S.D.N.Y. Dec. 22, 2010).

186. Id.

187. Id.

188. Amended Complaint at 11-12, Absolute Activist Value Master Fund Ltd. v. Homm, 2010 WL 5415885 (S.D.N.Y. Dec. 22, 2010) (No. 09 CV 8862).

189. Id. at 12 
"to the point at which [the] [d]efendants were free to sell previously untradeable shares and exercise certain warrants, which [the] [d]efendants then sold to the Funds at a profit." ${ }^{190}$ These intra-Funds trades also served to generate commissions for certain of the defendants acting in a brokerdealer capacity. ${ }^{191}$ The amended complaint asserted claims under Section 10(b) and Rule 10b-5 as well as common law claims for fraud and breach of fiduciary duty. ${ }^{192}$

The United States District Court for the Southern District of New York dismissed the amended complaint based on Morrison. ${ }^{193}$ In relevant part, the order provided:

Defendants, with the exception of [Todd] Ficeto and Hunter [World Markets, Inc.], are foreign nationals. The corporations that issued the Penny Stocks were registered with the SEC, however, their shares were not traded on a domestic exchange. Instead, the fraudulent scheme alleged involved private offerings [registered with the SEC] . . in which the Funds were caused to purchase the illiquid shares directly from the companies through private placements. At no point were the shares released to the general market. In fact, the entire "market" alleged was the trading by and between the Funds. ${ }^{194}$

Consequently, the court found that dismissal was warranted because the Funds' trades did not satisfy the transactional test. ${ }^{195}$

In reaching its holding, however, the court appears to have been preoccupied with the manner in which the Funds initially acquired the securities such that it failed to consider the impact of the subsequent intraFunds trades used to inflate the securities' prices. ${ }^{196}$ Moreover, the court's application of the transactional test was limited to evaluating whether the trades constituted "transactions in securities listed on domestic exchanges" under the first prong of the test without considering whether the trades qualified as "domestic transactions in other securities" under the second prong of the test. ${ }^{197}$ As noted previously, two of the defendants, Todd

190. Absolute Activist, 2010 WL 5415885, at*3.

191. Id.

192. Amended Complaint, supra note 188, at 56-60.

193. Because oral argument on the defendants' motion to dismiss was held one day before the Supreme Court issued its opinion in Morrison, the parties were not given an opportunity, either orally or in writing, to address the transactional test's impact on the Funds' claims. Absolute Activist, 2010 WL 5415885, at *4.

194. Id. at *5. The various penny stock companies' shares, however, were either quoted on the Over the Counter Bulletin Board or by Pink OTC Markets Inc. Amended Complaint, supra note 188, at 2.

195. Absolute Activist, 2010 WL 5415885, at *5-*6.

196. The court's analysis similarly fails to account for the eventual sale of the defendants' personal holdings to the Funds.

197. Morrison III, $130 \mathrm{~S}$. Ct. at 2884. 
Ficeto and Hunter World Markets, Inc., were California residents. Significantly, Hunter was the registered broker-dealer responsible for executing the intra-Funds trades alleged in the amended complaint. ${ }^{198}$ Ficeto, meanwhile, was Hunter's president and a registered securities agent in several U.S. states. ${ }^{199}$ Thus, although the buy and sell orders for the intra-Funds trades may have originated in Europe, the actual trades arguably took place in the domestic over-the-counter market such that they satisfy Morrison under the newly-clarified transactional test. ${ }^{200}$ At the very least, the parties should have been given an opportunity to brief the impact of Morrison so that a better-developed factual record would exist regarding the precise nature of the intra-Funds trades. ${ }^{201}$

\section{CONCLUSION}

In announcing the transactional test, the Morrison Court sought to create a new, bright-line rule that would avoid the unpredictability and inconsistency of the conduct and effects tests. In application, the transactional test has thrust a reasonably well-settled area of the law into abject confusion. This outcome was inevitable in light of the Court's inability to commit to a single articulation of the test and its concomitant failure to define the test's precise scope and contours. Nonetheless, this Article argues that by examining the statutory text from which the transactional test was derived, a bright-line rule may still be salvaged from Morrison.

198. Amended Complaint, supra note 188, at 6, 8, 11-13, 15-16, 22-23, 26, 31, 34, 38, $41,51$.

199. $I d$. at 5,8

200. Cornwell v. Credit Suisse Group, 729 F. Supp. 2d 620, 623 (S.D.N.Y. 2010); Plumbers' Union Local No. 12 Pension Fund v. Swiss Reinsurance Co., 753 F. Supp. 2d 166, 17 (S.D.N.Y. 2010); In re Société Générale Sec. Litig., No. 08 Civ. 2495, 2010 WL 3910286, at *5-*6 (S.D.N.Y. 2010). The Funds subsequently raised this argument on appeal. Reply Brief for Plaintiffs-Appellants at 6-10, Absolute Activist Value Master Fund Ltd. v. Ficeto, No. 11-221 (2d Cir. July 21, 2011).

201. See Anwar v. Greenwich Ltd., 728 F. Supp. 2d 372, 405 (S.D.N.Y. 2010) (finding "that a more developed factual record is necessary to inform a proper determination as to whether [the] [p]laintiffs' purchases . . . occurred in the United States"); see also Painter et al., supra note 116, at 7 (noting that although "the vast majority of over-the-counter transactions ... occur in one country or another . . situations occur where the location of the transaction is ambiguous"). 